\title{
Synergy Between Police Officers and Nagari Governmental Officers Through Community Policing Program (Polmas) In the Prevention of Crime In West Sumatera, Indonesia
}

\author{
Aria Zurnetti ${ }^{1}$, Riki Afrizal ${ }^{2}$, Nani Mulyati ${ }^{3}$ \\ \{ ariazurnetty@law.unand.ac.id ${ }^{1}$, rikifhunand@gmail.com², nanimulyati@law.unand.ac.id ${ }^{3}$ \} \\ Criminal Law Department, Faculty of Law, Andalas University, Padang, Indonesia
}

\begin{abstract}
Crime as a social phenomenon causes various problems and become a threat to security and peace in society, and it can also be a disruption to the implementation of development. The development of society generates the increasing quantity and quality of the crime rate. This situation leads to the rising number of people who is afraid of the crime (fear of crime). Statistics data from the National Bureau of Statistics (BPS) indicates a growing of crime rates both nationally or locally, including in West Sumatra. To address these crime issues there needs to be an effective and efficient crime prevention policies and strategies and by the existing situation and conditions. One of the crime prevention policy is by involving the community at large. So, not only done by law enforcement officers especially the police but through the policy of Community Policing or called Polmas. This approach tries to exploit the potential of society for crime prevention. For West Sumatra with Minangkabau, Customary Law has the potential to overcome crime through living values, especially through Nagari with all its potential, either government or its citizens. Therefore there should be a study on how the synergy of law enforcement officers namely the police in tackling crime through the Nagari-based Polmas. The research will be conducted by the empirical juridical method by selecting three districts as research locations. In each district will be selected a Nagari as a sample by using the sampling method. The data were collected through in-depth interviews with respondents and resource persons, i.e. from ninik mamak (community leaders) in Nagari, Nagari governmental officers and related law enforcement officers. Data then processed and analyzed by the qualitative juridical method. The results of the research are (1) Police policy through the doctrine of Polmas in crime prevention in West Sumatra has not run optimally because of the still high crime rate that happened in West Sumatra jurisdiction; (2) the synergy between police officers with the elements of Nagari governmental officers in realizing the goal of policing the crime in West Sumatera has been running but needs to be improved in the form of prevention of crime involving the functionaries of customary law, clergy, and cadiak pandai (scholars) in the community; and (3) there are still obstacles in the implementation of Polmas for crime prevention in West Sumatera.
\end{abstract}

Keywords: Police Synergy, Nagari, Community Policing (Polmas), Crime Prevention. 


\section{Introduction}

Crime is an issue that is always a concern not only for academics but also for every person and government in every country. Crime is a form of human acts that incur losses not only to the victim but also to the public, especially for public peace and security in general. In a narrow meaning, a crime is defined as an unlawful act, in particular, defined by a State or positive law.

The issue of crime as a social phenomenon occurs in all countries including Indonesia. The more aggressive the symptoms of crimes, the more restless the public because of its increase over time. According to data from the Indonesian Central Bureau of Statistics (BPS) during the year of 2016 occurred 352,936 crimes. This figure increased from the previous year, ie 325.317. This number also indicates that the crime clock was 01'29 ' (1 minute 29 seconds) in 2015. Meaning that every 1 minute 29 seconds crime happens in Indonesia. While the crime rate is 140 per 100,000 populations, it means that 140 people out of 100,000 Indonesians are potentially exposed to crime [1].

Many regions in Indonesia including West Sumatra, of course, encounter the same problem. BPS data shows that West Sumatra is ranked 6th of the total crimes according to the Regional Police (Polda) respectively. While viewed from the Crime rate, West Sumatra is ranked second nationally. This means that the potential of the affected population is 317 people of the 100,000 populations. The figure is slightly lower compared to the Special Region of Jakarta (DKI), which are 328 per 100,000 populations. The figure is far above the national average of 140 per 100,000 populations [1].

Given the above issues, it is necessary to have an appropriate policy on crime prevention, either nationally or locally, especially for West Sumatra. Because without a proper policy, the issue of crime will be more serious and will result in various impacts that can hinder the achievement of development goals. Most importantly, the high number of crimes will give rise to disturbances for public order, security and public peace.

Crime prevention is a process that uses criminal law as an attempt to overcome the problems related to crime. In particular, the prevention of such crimes is in order to achieve the ultimate goal of the criminal policy itself, namely to protect the people in order to achieve prosperity for the community. Counter-crime is part of the criminal policy. According to Marc Ancel, the criminal policy is a reasonable effort of society in tackling crime [2]. The definition of criminal policy is also stated by G. Peter Hoefnagels that, "criminal policy is the rational organization of the social reaction to the crime." One effort to prevent and overcome the problem of crime is to use penal law. The criminal policy requires a comprehensive approach involving various disciplines of laws.

Among the criminal subsystems, the police institution stands on the frontline. Since the main function of the police in criminal law is as an investigator, the police are at the forefront. Therefore, the police must function and play an optimal role so that law enforcement and crime prevention run optimally by the expected results.

As an institution specifically mandated by law to create and maintain order and security in society, in consideration of Law No. 2 of 2002 on Police states that internal security is the main requirement to support the realization of a just, prosperous and civilized civil society based on Pancasila and the Constitution of the State of the Republic of Indonesia Year 1945. It further states that the maintenance of internal security through the efforts to organize the police functions which include the maintenance of security and public order, law enforcement, protection, guidance and service to the community is carried out by the Police of the Republic of Indonesia (Polri) as the state instrument assisted by society by upholding human rights. All 
the functions of the police force are unity and cannot be separated from each other. The success of one function will support the achievement of the other functions.

Police in the execution of such functions certainly cannot be alone but will always be explicitly associated with other subsystems and in general all components of society and government. From the aspect of social life, the existence of the police is basically inseparable from the life of the community itself. The relationship between the police and the community affect each other or more precisely the existence of the police is in the public interest. Police and the community complement each other and strengthen crime prevention efforts. The policing of this model are not done to fight crime, but to seek and eliminate the source of the crime. This concept is known as Community Policing. The success of the community policing is not to suppress the number of crime but when crime does not occur [3].

Given such a function, the police must coordinate with all components of society, especially with the government. For the region of West Sumatra, with the development of thinking about autonomy, then West Sumatra has the lowest form of government called Nagari. In Article 1 point 7 of Regulation No.9 of 2000 concerning the Basic Provisions of Nagari Government, it is stated that Nagari is a unit of customary law community in West Sumatera, consists of several tribes whose territory has certain limits, owns their own assets, and is entitled to arrange and manage its household, and elect its government leader. Then in the Law No. 2 of 2007 on the Principles of Government Nagari that replace the Law no. 9 of 2000, in Article 1 point 7 states that Nagari is a unitary customary law community which has certain territorial boundaries, and is authorized to organize and manage the interests of local communities based on the Minangkabau adat philosophy (Adat Basandi Syarak, Syarak Basandi Kitabullah) and or based on origins and local customs within the province of West Sumatra. With the existence and recognition of the Nagari as the lowest government in West Sumatera especially in the district government area, the Nagari has the potential to carry out government puncture by the situation and condition of West Sumatra with Minangkabau indigenous people, including the problem or the effort of crime prevention. Crime prevention is not just the duties and authorities of law enforcement officials, but must also involve variously related apparatus, including the society.

Therefore, it is necessary to examine the synergy between police and the Nagari in the effort to overcome the crime, so that it can be taken a policy appropriate to the situation and condition of the region in order to create effective and efficient countermeasures.

This paper tries to answer three research questions, first is how the police policy in the implementation of the doctrine of Polmas in Crime Countermeasures in West Sumatra is? Secondly is how does the police synergy with the elements of Nagari government in realizing the objectives of Polmas in order to address the prevention of crime in West Sumatra? Moreover, the last question is what are the constraints faced by the police in implementing the Polmas for crime prevention in West Sumatra.

In order to answer those questions, a research methodology that is employed is normative (doctrinal) legal research and sociological/empirical (non-doctrinal) research. This research will undertake an inventory of existing legal principles and rules of law and Minangkabau adat law relating to crime prevention in the Nagari and applied by customary settlement institutions, in this case, Nagari Customary Density or other forms known to the public.

To conduct research related to the implementation of adat values is continued with research concepts and norms in the prevention of crime and how the application by Nagari. While the implementation of sociological research regarding the concept of understanding, the existence of recognition of customary law in the community, and the formal law enforcement officers, namely the police, especially in the framework of Polmas policy implementation. 
This research is conducted directly to the community or by conducting empirical legal research.

\section{Police Policy In The Implementation Of Polmas Doctrine In Crime Prevention In West Sumatera}

Based on the results of research conducted in Pasaman, Lubuk Basung, Tanah Datar, and Pesisir Selatan, there are several policies conducted by the police in the implementation of the Doctrine of Polmas in crime prevention. Polmas activities in Nagari are carried out by Babinkambtibnas (local police) and involve the role of the Nagari government as well as kejorongan and Babinsa (TNI elements). Baginkambtibnas together with the Nagari government is at the forefront in anticipating or even resolving the problems or disputes arising in the community. The anticipation of disputes or problems is carried out by conducting scheduled extension activities to the public at the level of kejorongan as well as performing activities of silaturrahmi / approach to the community by visiting every day and sitting together or blending in the middle of society. The same thing is also found in Pesisir Selatan, Pandai Sikek Tanah Datar, and also Padang City.

The most prominent forms of crime in the jurisdiction of West Sumatera Regional Police in 2017 are grand theft or pencurian dengan pemberatan (curat), robbery or pencurian dengan kekerasan (curas), stealing motor vehicles or curanmor, torture or anirat, drugs and gambling in the most prominent figures in Resta Padang, Pesisir Selatan, Tanah Datar, Agam and Pasaman Barat.

\section{The Synergy Between Police and The Element of Nagari Government in Realizing Polmas Objectives to Address Crimes in West Sumatra}

Through a Memorandum of Understanding (MoU) between the West Sumatera Regional Police Chief on Police Synergy with Minangkabau Traditional Council (LKAAM) in the Framework of HarKambtibmas and the Settlement of Social Issues through Minangkabau Adat Approach Local Wisdom at the Police and Community Partnership Center (BKPM) no. B / 2618 / VII / 2017 can be used as guidance in the purpose and objectives as follows:

1) Can be used as guidance for stakeholders in settlement of social issues as well as matters that have the potential to cause disturbance of public order and security by helping to resolve community disputes that may disrupt public order by prioritizing deliberations for consensus as outlined in the consensus letter.

2) The purpose of this collective agreement is the realization of organizing activities to raise awareness and build optimistic attitude towards anak kemenakan as the heir of Minangkabau adat in order to realize the future of the Indonesian nation through preventive efforts in order to create a situation of security by conducting public order.

The scope of the Memorandum of Understanding can be in the form of information exchange, solving social problems, and socialization. In practice, exchange of information in the form of: 
1) The parties exchange information in the implementation of social problem solving as well as matters that potentially cause disturbance of security and order in society by helping to resolve community disputes that can disrupt public order.

2) The parties exchange information on public reports / complaints about matters that cause disturbance of security and order in Minang indigenous communities.

The settlement of social problems as governed by section two of Article 4 is as follow:

1) The Parties undertake joint guidance on the people in Nagari Jorong Village / kelurahan to raise awareness and adherence of citizens to laws that apply.

2) The Parties undertake active coordination in providing data and information on the potential threats to the kamtibmas disruption that will arise in the community.

3) The parties have a good and harmonious cooperation between the police and traditional leaders, religious leaders, community leaders (cadiak pandai), youth leaders, female figures (bundo kanduang) in the nagari / jorong / desa / kelurahan.

4) The first party to make efforts to prevent the incidence of community disease as well as increasing the power of deterrence and prevention power of citizens against the disorder of the Kambtibmas.

5) The parties play a role in providing solutions in handling the problems/disputes of the anak kemenakan and citizens and potential interference and threshold disturbances that occur so as not to develop become real trouble to Kambtibmas

6) The parties participate actively in problem solving by acting as mediators, negotiators, and facilitators in settlement of social problems that occur in the community nagari / jorong / village / kelurahan.

In this synergy policy also needs to be set obligations and responsibilities in the form of:

1) By its main duties, functions and roles, the police through Polmas is obliged to receive reports/complaints of the public on matters which potentially cause disturbance of security and order within the Minangkabau indigenous people and is responsible for providing legal guidance and counseling.

2) The LKAAM and its staff in the nagari also through KAN are responsible for guiding the Minangkabau indigenous people through existing local wisdom approaches.

3) Parties undertake coordination in the promotion of Kambtitmas with the village / jorong / kelurahan equipment, BabimKambtibmas, Babinsa, walinagari, traditional leaders, religious figures, community figures (cadiak pandai), youth figures, female figures (bundo kanduang), and other stakeholders in mediation as well as facilitating the problem-solving efforts that occur in the community.

The above policies are implemented in various regions and villages as seen at Sub Salido South Coastal District, Kenagarian Pandai Sikek Regency Tanah Datar, and West Pasaman and Regency of Agam and Lubuk Basung. So, in conclusion, the rules written through the Nagari rule do not yet exist, only the new form of policy is unwritten through mutual agreement between Kepolisian, Nagari government, involving elements of babinsa (TNI), religious scholars, and ninik mamak. These agreements are in different forms and ways according to their respective villages.

Related to the crime prevention program in Nagari usually done with the extension activity to the community, which is held in every kejorongan and involves the role of ninik mamak as the responsible for anak kemenakan. In the case of criminal in mild category, can be solved at community level only involving Babinkamtibmas together with ninik mamak or 
Nagari government. The resolution is done with the mediation of the parties involved. Form of completion in the form of deliberation, consensus by pressing restorative justice, and does not blend into the judicial path.

In the implementation of Polmas duties as a manifestation of the policy outlined in Kapolri Decree No. 618 / VII / 2014 dated July 29, 2014, on Smart Book of BhabimKambtibmas and followed up in the regulation of the head of state police are:

1) Collect data, identify

2) Participate in taking a proportional step

3) Discuss social issues of Kambtibmas

4) Discuss and define a work program

5) Submit a work plan/program

6) Implement work program

7) Monitor the activities of citizens from the aspect of security and order

8) Accept complaints of the community related to the problem of Kambtibmas include:

The mechanism of handling reports and complaints by the community Polmas officers

1) Receive reports and complaints from the community and follow up on RT and RW levels involving youth leaders.

2) Problem-solving involves lurah, ninik mamak, babinsa and both parties

3) After a peaceful deliberation, a statement is made and signed both sides are known by RT, RW, Babinsa, lurah (3 pillars).

4) In the event of no settlement, then settled in the mediation palanta.

\section{Obstacles Facing By Police in The Implementation of Polmas Based on Data in The Field}

Based on interviews in the field, the following constraints are related to the human resources of Polmas [4]:

1) Competence of Polmas officers, Polmas Officers who directly face to face with the community must be equipped with capabilities in various fields, especially the field of intelligence, social community, binmas, and reskrim, and all areas of police obligations, especially in the field of social obligations to the society.

2) Polmas Behavior, The need for integration between the police community, especially social relations, community and a good example, to unite in the implementation of tasks. And if there are bad behaviors like extortion and corruption during this time will reduce society's sympathy. The arrogant attitude of some police officers is very influential in the implementation of Polmas duties, especially babinkambtibmas that must be integrated, down to the mosque, to the school, and to social events conducted by the community, even helping to supervise trains through the accident-prone crossings.

3) The distance of the residence of Polmas officers and the extent of the working area coverage, this issue also becomes an obstacle in the case of problems if the public will report in quick time can not be realized because the officer babinKambtibmas it only represented one chairman and vice in every kenagarian and kelurahan while time service is $1 \mathrm{x}$ per 24 hour. 
4) Lack of public legal awareness in the understanding of Polmas, the lack of public understanding of the existence Polmas resulted bad partnership between police and the community.

5) The Age factor and the age of Polmas personnel, most of the personnel stationed in this kambahbmas position usually are of old age, close to their retirement time. This is not proportional to the severity of the task and the coverage of the territory to be served.

6) Budget support factors, the budget support is not proportional to the length of time and the task of the personnel in a day, for every officer is given $\mathrm{Rp} \mathrm{50,000} \mathrm{for} 22$ days with $1 \times 24$ hours for the execution of their duties.

7) Infrastructure facilities, it is also very influential in the implementation of the task. In Pesisir Selatan [5], there is already a Community Policing nagari building that was established in cooperation but currently there are no activities because the budget is not available in the building operations and activities to be carried out.

\section{Conclusion}

From the study that has been done can be concluded few points:

1) Police Policy through Polmas doctrine in crime prevention in West Sumatera through Memorandum of Understanding (MoU) between West Sumatera Regional Police Chief and Chairman of Minangkabau Traditional Council (LKAAM) No.158 / LKAAM-SB / VII / 2017 on the Synergic between Police with LKAAM in maintaining the security and public order and solving social problems through Minangkabau adat approach and local wisdom in the Police and Community Partnership Hall (BKPM) as a follow up of the Police Chief Regulation (Perkap Kapolri) No. B/2618/VII/2017 and No. 158 LKAAM - SB /VII/2017 on Community Policing (Polmas) which in its implementation has not been optimal in the prevention of nagari-based crime via babinKambtibmas.

2) Police synergy with the elements of nagari government in realizing Polmas goals in tackling crime in West Sumatra has been implemented but needs to be improved in the form of prevention of nagari based crime involving the functionaries of customary law, clergy, and cadiak pandai in the community.

3) There are still obstacles in the implementation of Polmas for crime prevention in West Sumatra, especially based on nagari.

Based on those conclusions mentioned above, there are some suggestions for the improvement of the implementation of Polmas in crime prevention:

1) It is suggested to policy makers to improve the quality of human resources of Polmas officers by providing training, education and counseling.

2) In order to synergize it is important to the community to work together with the authorities in the crime prevention in the nagari.

3) To the officers and the community to carry out Polmas duties in accordance with No. Perkap. 3 years 2015 .

4) To provide an adequate budget and prepare the means to support the implementation of Community Policing according to its aim.

\section{References}


[1] Central Bureau of Statistics Indonesia (BPS). 2016, Statistik Kriminal 2016 (20016 Criminal Statistics), BPS, Jakarta, p. 25. https://bps.go.id/website/pdf_publikasi/Statistik-Kriminal2016.pdf, accessed at 20 Agustus 2017.

[2] Arief, Barda Nawawi. 2016. Kapita Selekta Hukum Pidana tentang Sistem Peradilann Pidana Terpadu. Badan Penerbit Undip: Semarang

[3] Rahardjo , Satjipto. 2007. Membangun Polisi Sipil, Perspektif Hukum, Sosial dan Kemasyarakatan. Penerbit Buku Kompas: Jakarta

[4] Interview with Kasat Polresta Padang, Kompol John Hendri, SH, on Friday 2017 at 11.00 WIB.

[5] Interview with wali nagari and the chief of adat office (KAN) Salido, in 2017. 